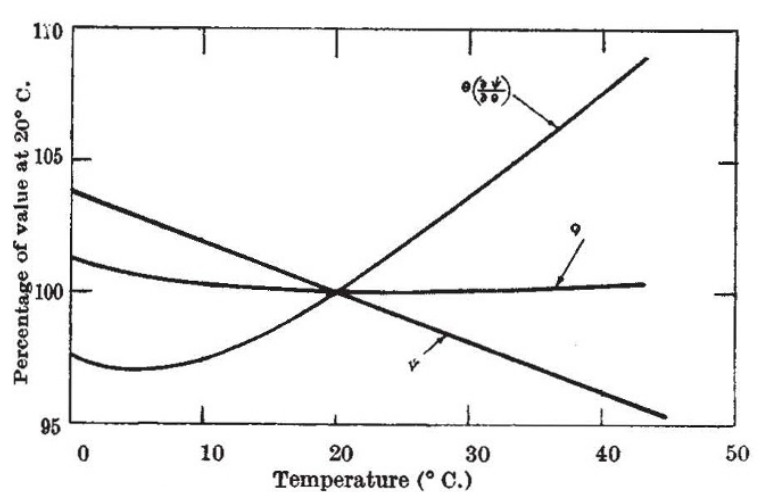

Fig. 4. Temperature variation of capillary potential, $\psi$, heat of wetting and bound energy, $\theta(\partial \psi / \partial \theta)$

$$
Q_{\theta_{1}}=Q_{\theta_{3}} \frac{\left[\frac{1}{T_{\theta_{1}}}\left(\begin{array}{c}
\partial T \\
\partial \theta
\end{array}\right)_{\theta_{1}}-\frac{1}{\theta_{1}}-\frac{1}{\rho_{\theta_{1}}}\left(\frac{\partial \rho}{\partial \theta}\right)_{\theta_{1}}\right] \theta_{1} \cdot T_{\theta_{1}} \rho_{\theta_{2}}}{\left[\frac{1}{T_{\theta_{2}}^{\prime}}\left(\frac{\partial T}{\partial \theta}\right)_{\theta_{2}}-\frac{1}{\theta_{2}}-\frac{1}{\rho_{\theta_{2}}}\left(\frac{\partial \rho}{\partial \theta}\right)_{\theta_{2}}\right] \theta_{2} \cdot T_{\theta_{2}} \rho_{\theta_{1}}} .
$$

Equation (5) can be written in the form

$$
Q=\psi-\theta d \psi / d \theta
$$

where $\psi$, Buckingham's capillary potential, $-g h$, is given by

$$
\psi=\frac{R \cdot \theta}{M} \cdot \log _{e} \frac{H}{100} .
$$

In Fig. 4 the temperature variation of $Q$ and each of its components $\psi$ and $\theta . \partial \psi / \partial \theta$ is given. These curves are based on equation (7). The quantity $\partial T / \partial \theta$ was obtained from accurate surface tension data.

- Further investigations are in hand, and it is hoped to publish a fuller account, including experimental results, in due course. The work is being undertaken as part of the programme of the Road Research Board, and the present note is published with the consent of the Director of Road Research.

${ }^{1}$ Schofield, R. K., Trans. 3rd Inter. Cong. Soil Sci., 2 (1935). 'Shorter, S. A., J. Tex. Inst., 15 (1924).

'Buckingham, E., U.S. Dept. Agric., Bur. Soils, Bull. No. 38 (1907).

$$
116
$$

\section{DEVELOPMENTS IN PICTURE TELEGRAPHY}

$\mathrm{T}$ HE transpaissto of pictures by land-line over various distemes Apreen the subject of experimental defelon ment since the earliest days of telegraphipogrmunication; and the techniques involved haye bepn adapted similarly for transmission or raving over radio links. Amid the excitement of othor applications in recent years, such as broadcasting, radar and television, the very advanced stage which has been attained by picture or facsimile telegraphy, as the technique is termed, is apt to be overlooked. Many systems have been suggested and experimented with; but they have had a common besis in that the picture to be transmitted is placed on a revolving drum and scanned with a suitable source of light and optical system. The variations in light intensity reflected or scattered by the varying tones of the picture are converted into a fluctuating electric current through the agency of a photoelectric cell. 'The resulting signals are transmitted by line or radio to the receiving station, where they may be converted by a current-sensitive oscillograph into light variations which record the picture on suitable photographic paper. Alternatively, the electric currents are made to reproduce the picture by an electrochemical process. In either case, the recording paper is mounted on a drum which is maintained in rotation synchronously with that at the transmitting station.

This technique of the transmission of pictures by telegraphy is used to a large and successful extent by the Press to obtain quickly the illustrations which accompany accounts of topical events all over the world. But there are other applications in industry and the public service; and one of these, the transmission of fingerprints by radio, has been referred to in Nature, 158, 525 (1946).

The name of Muirhead has been associated for more than a century with the development of instru. ments used in various branches of telecommunications, including in recent years the very successful production of phototelegraphic equipment. At the recent symposium held by the Scientific Instrument Manufacturers Association of Great Britain, Ltd., a paper entitled "Some Developments in Picture Telegraphy" was presented by Mr. J. Bell, of Muirhead and Co., Ltd., who have also supplied some technical literature and bulletins giving further details of the equipment. For some time now a number of the larger newspapers have operated their own picture transmission circuits comprising telephone lines linking their editorial offices with various population centres; and Muirhead-Jarvis picturetelegraph transmitting and receiving equipment is now in operation in a large number of newspaper offices in Great Britain and northern Europe. The apparatus has been designed to conform with the requirements laid down by the Comité Consultatif International Télégraphique (C.C.I.T.), and it may therefore be worked with the principal phototelegraphic services abroad which conform to the same standards.

An amplitude-modulated form of transmission is used over wire circuits, while for radio links the principle of sub-carrier frequency-modulation is used, thereby ensuring that the signals representing the tone values of the picture are not greatly affected by fading and other disturbances of the radiofrequency carrier-wave during transmission. The picture transmission band is from 300 to 2,300 cycles per second and is thus easily within the scope of a normal telephone channel.

The standard equipment installed at the terminal fixed stations uses drum speeds of either 1 or 2 revolutions per second, and the picture is scanned at either 100 or 150 lines per inch $(3.9$ or 5.9 lines per $\mathrm{mm}$.) for all normal requirements. Under these conditions, a picture of size $10 \frac{1}{2} \mathrm{in}$. by $10 \mathrm{in}$. $(267 \mathrm{~mm}$. by $254 \mathrm{~mm}$.) can be transmitted in $16 \mathrm{~min}$. $40 \mathrm{sec}$. and $25 \mathrm{~min}$. respectively. For super-quality work, scanning at 300 lines per inch (11.8 lines per mm.) can bo used, and the results obtained under these conditions are so accurate in detajl as to render it difficult to distinguish the received picture from the original.

The use of normal telephone channels for the communication of news direct from the scene of the event has been followed by a demand for com. parable facilities for the transmission of pictures, and the Muirhead-Belin portable transmitter has been developed to meet this demand. This equipment 
consists of two suit-case units, one of which contains the power unit operating either from the electricity supply mains or from a car-starter battery. The other unit comprises the transmitter, which conforms with the C.C.I.T. requirements as regards pieture size, rate of scanning, synchronizing, phasing and speed of transmission; it can therefore be used in conjunction with any make of receiver similarly standardized. As with the fixed station equipment, the speed of the revolving drum carrying the picture is maintained constant by means of a special synchronizing circuit controlled by a temperaturecompensated high-stability tuning fork. The frequency of this fork is $1,020 \mathrm{c} / \mathrm{s}$., and this is used to modulate a sub-carrier signal of $1,300 \mathrm{c} / \mathrm{s}$., which is transmitted down the line, to provide at the receiver a synchronizing signal which is independent of any changes occurring in the telephone carrier-signal.

There is also available a portable dark-room, comprising a small tent and full photographic facilities, and this is fitted up in two suit-cases for use with the portable picture transmitter. This equipment allows the processing of pictures to be carried out quickly and conveniently in any location.

The bulletins referred to above contain several photographic reproductions in support of the claim that "Muirhead machines are producing the best wired pictures in the world".

\section{ifl \\ ANCIENT ARTS AND MODERN PARODIES}

T HË exhibition entitled "40,000 Years of Modern Art", which opened at the Academy Hall in Oxford Street, London, just before Christmas and closes at 10 p.m. on January 29 , makes no claim to a scientifig appor ch-to which, indeed, so cavalier a title of ald a $\mathrm{f}$ been rather ill attuned-yet it posepses sr rpastung interest for anthropologists, and mat well do a good service to science by inducing them, and other visitors, to look at primitive art in new ways under the shock of the juxtaposition with a sufficiently aggressive selection of modern paintings and sculptures. The Institute of Contemporary Arts, 6 Fitzroy Street, London, W.1, a recently formed body devoted to the good cause of encouraging new trends in all the arts (but the approach of which is perhaps not yet quite so wide as its scope), is to be warmly congratulated and thanked for assembling what is almost certainly the most impressive display of primitive art ever held in Great Britain outside the great ethnographical museums.

The selection, though partly conditioned by the desire to find parallels for the moderns, has not suffered unduly thereby, and there are only a few pieces (such as a dubious Easter Island figure) which seem to have been included less for their merit than their surrealism. Many, if not most, of the Oceanic and (especially) African pieces are of the very first class within their types; some cannot be paralleled here at all. The Pitt Rivers and Ashmolean Museums at Oxford, the Horniman Museum and the Brighton Museum have all made notable contributions, and the magnificent private collections of Mr. Webster Plass and Mr. W. O. Oldman have been drawn upon to excellent effect. Among the finest pieces are the most forceful of all Basonge masks (Belgian Congo), owned by Mr. R. Penrose; Mr. Plass' bust of a Baga fertility divinity (French Guinea); the Northern Yoruba earth goddess from the Horniman Museum; two large fetish figures of the eastern and western Belgian Congo from the Oldman collection; some fine reproductions from the Frobenius Institute at Frankfurt of Australian and African rock paintings; and an outstanding series of polychrome malanggan carvings from the New Ireland collection at Brighton. The word 'primitive' has been rather strictly interpreted, to exclude the barbaric 'civilizations' of West Africa, Indonesia and pre-Columbian America, and this has meant that certain forms of sculpture preeminently appropriate to this exhibition (such as the more mystical of the Benin bronzes) are unrepresented. Less easy to explain is the truly primitive sculpture of Borneo and other parts of the East Indies.

The declared purpose of the exhibition is to compare primitive and modern and to suggest a community of inspiration between them. But one's main impression on leaving the show (and this is confirmed by most of the art critics) is rather of antithesis. It is true that there are superficial resemblances of form (though many of those to which the organisers direct attention are, in fact, purely fortuitous); but fundamentally they are opposed in conception and function. Primitive art is everywhere (even in medieval Europe) an art of conformity, of devoted acceptance in both a spiritual and a material sense; the forms develop over hundreds, or even thousands, of years, by processes which are essentially evolutionary, and have a four-dimensional quality about them which arises from their conception not by a single artist, but by many generations of artists, not as an escape, but as at once the expression and the support of the social pattern. 'Modern' art, on the contrary, is to a large extent frankly revolutionary, and, moreover, is still, after forty years, in the destructive phase of anarchism, comparatively few artists having begun, like Henry Moore (who almost alone in this exhibition seems to hold his own with the peoples of Nature), to build the foundations of a new order amid the chaos; too many of them are iconoclasts, content to satirize our world by drawing, for their purely intellectual inspiration, upon the form but not the content of the deeply religious art of the primitive peoples (with the same cynicism with which an atheistic totalitarianism will tolerate or even sponsor a subservient form of Christianity for its own ends). In this deeper sense, then, primitive art is actually nearer in spirit to the traditionalism of the Royal Academy than to the exuberance of its own imitators. Sincerity, it may be thought, is the most flattering form of imitation.

We may be all the more grateful to the Institute of Contemporary Arts for putting the moral so clearly before us that there is a virtual unanimity among both critics and members of the public. The Institute has thus laid a fine foundation for its future work, and we may look to it with confidence and hope for the constructive leadership which will not only give direction and stability to modern art in the postPicasso era, but also make its contribution to a re-integration of the cultural elements in our schizophrenic society.

Two further words should be said: the arrangement of the exhibition, though bold and imaginative, strains perhaps a little too self-consciously after the sales technique of a show of industrial design, instead of the self-effacement proper to the display of works 